\title{
BYZANTINE CROSSES WITH INLAY IN THE SOUTH-WESTERN CRIMEA ${ }^{1}$
}

\author{
Elzara A. Khayredinova \\ Institute of Archaeology of Crimea, RAS, Simferopol, Russian Federation
}

\begin{abstract}
Archaeological materials played an important role for the studies of the history of Christianity in the South-Western Crimea. Especially interesting are individual artefacts of Christian cult, pectoral crosses in particular. Crosses in costumes of the barbarians of the South-Western Crimea appear in the second half of the $6^{\text {th }}$ century. They were mainly mass goods that were brought from Byzantium and were manufactured in Cherson and jewellery workshops of the country of Dori. This paper analyses byzantine crosses from 550-625 AD with inlay. It was the earliest and the most popular type of crosses among the Crimean Goths. The location of beads and crosses documented in situ in graves provides arguments to reconstruct necklaces and costume which components they formed. Only women and girls wore these crosses in necklaces, accompanied with beads and varied amulets. Many necklaces contained several crosses, which could be explained as the understanding of cross as an amulet. Crosses, as other things of personal godliness, as well as numerous objects with Christian symbols, are a bright evidence of Christianity spreading in Crimea. Crimean finds enlarge our notion of everyday Christian culture in the early mediaeval period, thus forming a striking evidence of close economic and cultural relations of the Crimea and the Byzantine Empire in the early Middle Ages.
\end{abstract}

Key words: South-Western Crimea, The Crimean Goths, Byzantine applied arts, crosses, necklaces.

Citation. Khayredinova E.A. Byzantine Crosses with Inlay in the South-Western Crimea. Vestnik Volgogradskogo gosudarstvennogo universiteta. Seriya 4, Istoriya. Regionovedenie. Mezhdunarodnye otnosheniya [Science Journal of Volgograd State University. History. Area Studies. International Relations], 2017, vol. 22, no. 5 , pp. $86-99$ (in Russian). DOI: https://doi.org/10.15688/jvolsu4.2017.5.8

УДК 93/94;904

ББК $63.3(0) 4$
Дата поступления статьи: 17.06.2017

Дата принятия статьи: 10.07.2017

\section{ВИЗАНТИЙСКИЕ КРЕСТЫ С ИНКРУСТАЦИЕЙ ИЗ ЮГО-ЗАПАДНОГО КРЫМА ${ }^{1}$}

\author{
Эльзара Айдеровна Хайрединова \\ Институт археологии Крыма, РАН, г. Симферополь, Российская Федерация
}

\begin{abstract}
Аннотация. Для изучения раннего этапа истории христианства в Юго-Западном Крыму большое значение имеют археологические материалы. Особый интерес представляют индивидуальные пред- меты христианского культа, к которым, прежде всего, относятся нагрудные кресты. В статье рассматриваются кресты с расширяющимися концами, инкрустированные стеклом, бытовавшие во второй половине VI - первой четверти VII века. Их носили только женщины и девочки, в ожерельях вместе с бусами и различными амулетами. Во многих ожерельях присутствуют несколько крестов, что объясняется восприятием креста в качестве оберега. Крымские находки расширяют наши представления о повседневной христианской культуре раннесредневекового времени и являются ярким свидетельством тесных экономических и культурных связях региона с Византийской империей в эпоху раннего средневековья

Ключевые слова: Юго-Западный Крым, крымские готы, византийское прикладное искусство, кресты, (2) ожерелья.
\end{abstract}


Цитирование. Хайрединова Э. А. Византийские кресты с инкрустацией из Юго-Западного Крыма // Вестник Волгоградского государственного университета. Серия 4, История. Регионоведение. Международные отношения. - 2017. - Т. 22, № 5. - C. 86-99. - DOI: https://doi.org/10.15688/jvolsu4.2017.5.8

Византийский историк Прокопий Кесарийский в трактате «О постройках», в главе о деятельности Юстиниана I в Херсоне и на Боспоре сообщает о находящейся на этом же побережье области Дори, населенной готами - союзниками империи [33, p. 100-101, III, 7.13-17]. Исследователи локализуют область Дори в Юго-Западном Крыму - на территории от окрестностей Алушты и до низовьев реки Черная, где выявлена единая археологическая культуpa, представленная однотипными могильниками, поселениями и крепостями, построенными византийцами для местного населения. Анализ погребальных сооружений и обряда, антропологического материала и находок позволяет заключить, что все эти памятники принадлежали одному смешенному гото-аланскому населению [2, с. $311-$ $320 ; 16$, S. 96-104]. Около середины V в. у жителей области Дори распространилось христианство. Согласно письменным источникам, вплоть до 692 г. приходы области Дори принадлежали Херсонской епархии, а в период между 692 г. и 753 г. была основана Готская епархия, непрерывно просуществовавшая почти до конца XVIII в. [1, c. 617,623$]$.

Для изучения раннего этапа истории христианства в Юго-Западном Крыму большое значение имеют археологические материалы. Особый интерес представляют индивидуальные предметы христианского культа, к которым, прежде всего, относятся нагрудные кресты. На сегодняшний день известно около сотни таких крестов, выявленных в погребениях второй половины VIIX в. [12; 31]. По форме кресты представлены пятью типами, каждый из которых имеет несколько вариантов, отличающихся способом изготовления и декором. В предлагаемой работе рассматриваются кресты типа 3-2, сделанные с расширяющимися концами и инкрустированные стеклом на лицевой стороне (рис. 1), определяется время их бытования и круг аналогий. Все кресты происходят из могильника у с. Лучистое, где они были выявлены в захоронениях in situ. Последнее обстоятельство позволило нам реконструировать ожерелья, в состав которых входили кресты (рис. 2). В эпоху раннего средневековья жители Юго-Западного Крыма хоронили умерших в прижизненной, как правило, парадной одежде вместе с носившимися при жизни украшениями и индивидуальными предметами христианского культа. Поэтому изучение находок из погребений позволяет проследить обычай ношения нагрудного креста и значительно расширяет наши представления о повседневной христианской культуре раннесредневекового времени.

Кресты с расширяющимися концами типа 3-2 сделаны в виде бронзовой коробочки с вырезанной из пластины основой, по контуру которой напаян узкий пластинчатый бортик, а в центре - цилиндрическое гнездо (рис. $1, I)$. Полости между бортиками и внутри гнезда заполнены белой пастой, на которую укреплены плоские вставки из желтого прозрачного стекла. В круглом гнезде одного из крестов вставлено стекло треугольной формы (рис. 1,7). К верхней стороне крестов припаяна цилиндрическая петелька для подвешивания. Высота крестов - 2,73,2 см, ширина - 1,6-1,9 см. Все они плохой сохранности: тонкие металлически пластины сильно окислены и разломаны на мелкие фрагменты.

В могильнике у с. Лучистое самые ранние кресты описанного типа обнаружены в склепе 100, в детском погребении 11 с инвентарем второй половины VI в. (рис. $1,7,8)[13$, с. 190 , рис. 1,5$]$. В склепах 79 и 268 кресты лежали в детских захоронениях конца VI в. и рубежа VI-VII вв. (рис. 1,3,4,6) [13, с. 193; 4, рис. 11, 79]. В женских погребениях из склепов 102 и 122а кресты выявлены с вещами первой четверти VII вв. (рис. 1,1,2,5) [3, рис. 16, $17,18]$. Таким образом, бронзовые кресты, инкрустированные стеклянными вставками, бытовали в Крыму во второй половине VI первой четверти VII века. 


\section{ВИЗАНТИЙСКАЯ ТАВРИКА}
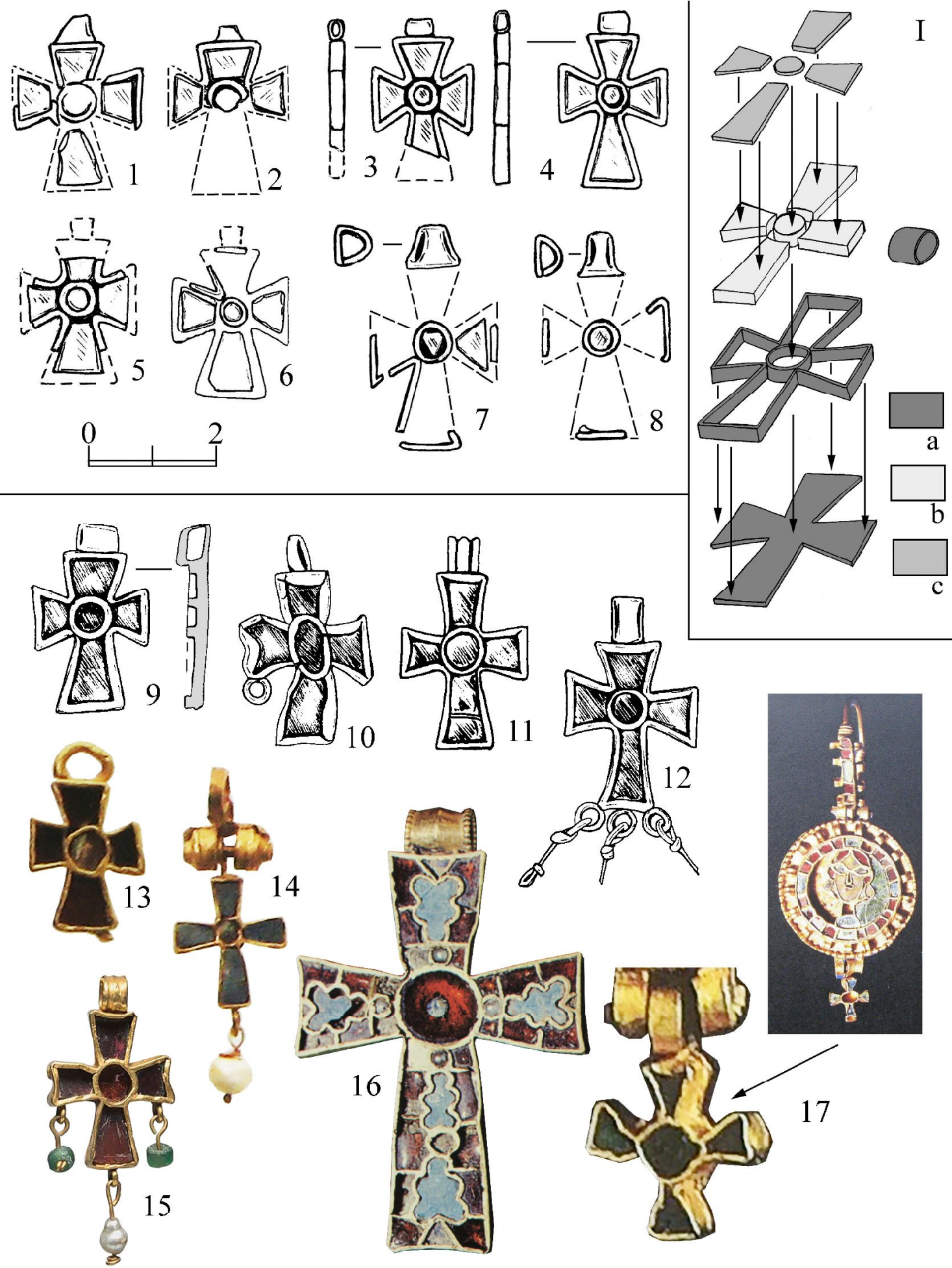

Рис. 1. Византийские кресты VI-VII вв. с инкрустацией:

$I-$ схема изготовления крестов ( $a$ - металлическая пластина; $b$ - пастовое заполнение; $c$ - вставки из стекла или камня); $1-8$ - Юго-Западный Крым, могильник у с. Лучистое;

9 - Болгария, крепость у с. Голеш; 10 - Турция, Аменуриум; 13-15 - Восточное Средиземноморье;

16 - Болгария, клад из Варны; 17 - Италия, клад из Сенизе

Fig. 1. Byzantine crosses with inlay of $6^{\text {th }}-7^{\text {th }}$ centuries:

$I$ - Cross manufacturing scheme; $1-8$ - South-Western Crimea, cemetery near the village of Luchistoye; 9 - Bulgaria, fortress near the village of Golech; 10 - Turkey, Amenurium; 13-15 - Eastern Mediterranean; 16 - Bulgaria, treasure from Varna; 17 - Italy, treasure from Senise 
Э.А. Хайрединова. Византийские кресты с инкрустацией из Юго-Западного Крыма

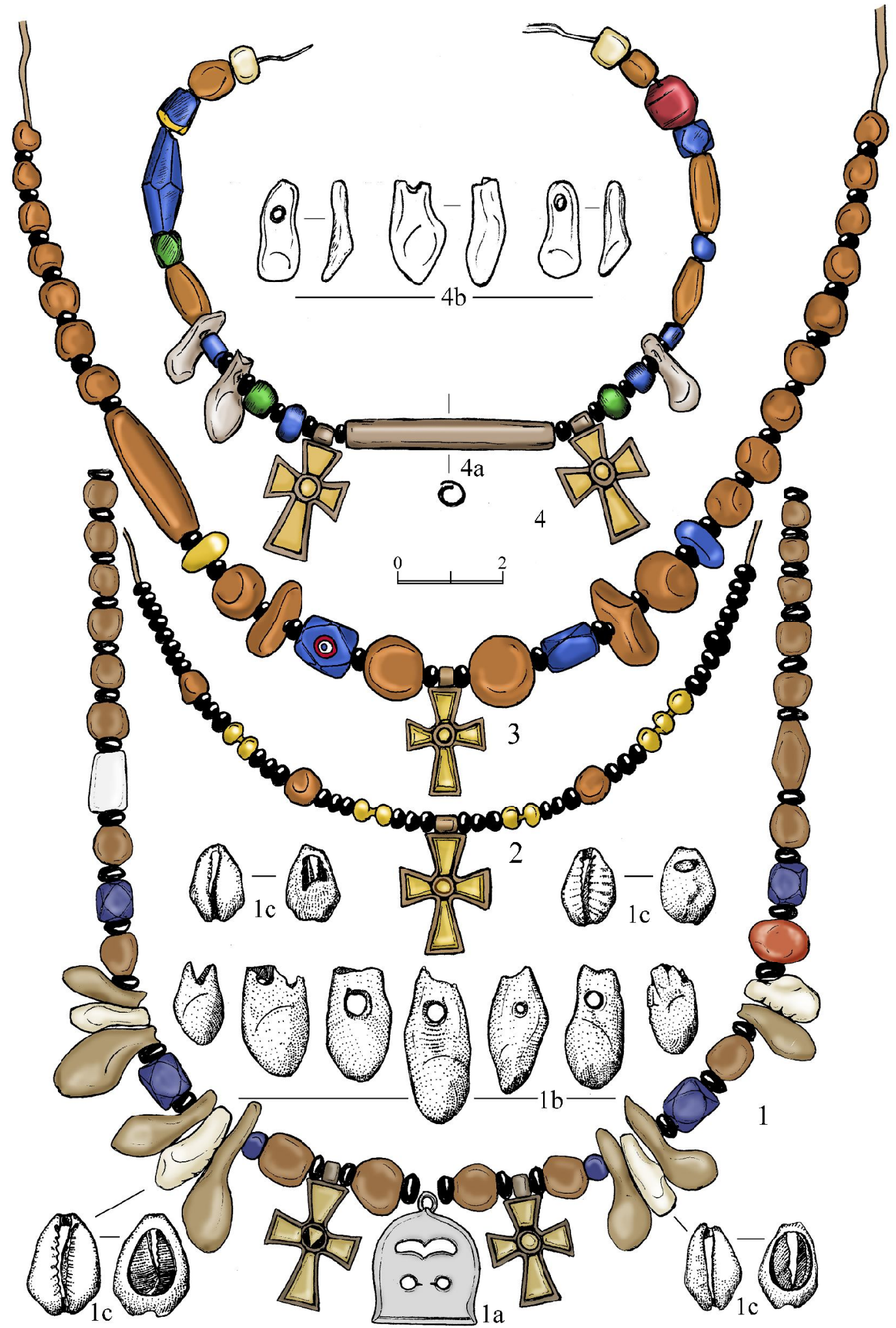

Рис. 2. Ожерелья с инкрустированными крестами второй половины VI-первой четверти VII в. из могильника у с. Лучистое

Fig. 2. Cemetery near the village of Luchistoye. Necklaces with inlaid crosses of the second half of the $6^{\text {th }}$ - first quarter of the $7^{\text {th }}$ centuries 


\section{ВИЗАНТИЙСКАЯ ТАВРИКА}

Крест, аналогичный крымским, обнаружен в Северо-Восточной Болгарии, в скальной нише колодца в ранневизантийской крепости у с. Голеш, вместе с находками VI в. [17, p. 138, Abb. 5, 10]. Бронзовые кресты из ЮгоЗападного Крыма и из Болгарии являются более дешевым вариантом византийских золотых крестов VI-первой половины VII вв., инкрустированных камнем или стеклом. Они найдены в Боснии и Хорватии, в Восточном Средиземноморье и в Малой Азии (рис. 1015) $[40$, p. 105 , tabl. I,4,5; 34, fig. 4,42; 23, Kat. Nr. 530, 531]. Обычно золотые кресты украшались вставками из альмандина, реже лазуритом. Своим богатством выделяется крест, найденный в Варне в составе клада VI в. (рис. 1,16). Его лицевая сторона декорирована фигурными вставками из малахита, стекла и жемчуга [38, Kat. Nr. 4]. К боковым и нижним ветвям некоторых крестов припаивались золотые проволочные подвески со стеклянной или перламутровой бусиной (рис. 1,14,15). Инкрустированные кресты использовались также в качестве подвесок в сложных украшениях (рис. 1,13,14). В Италии, в кладе VIII в. из Сенизе выявлена пара византийских серег золотых с круглым щитком, в нижней части которого на шарнире укреплен крест, инкрустированный гранатом (рис. 1,17) [21, fig. 262].

Золотые византийские кресты, бесспорно, были ювелирными изделиями. Крымские бронзовые кресты копируют в дешевом материале драгоценные прототипы и представляют собой продукцию массового производства, которая не только привозились на полуостров из империи, но и могла изготовляться местными мастерами, бравшими за образец импортные экземпляры. В эпоху раннего средневековья одним из центров ювелирного производства на полуострове был Херсон. На территории городища найдено несколько каменных матриц для отливки крестов, относящихся к периоду не позднее IX-X вв. [15, рис. $179,1,2 ; 180]$. Наличие каменных литейных форм, рассчитанных на множество отливок, свидетельствует о массовом, товарном производстве крестов. Одновременно в мастерских Юго-Западного Крыма в изобилии делали различные аксессуары одежды и украшения. Судя по этим изделиям, местные юве- лиры в совершенстве владели сложной технологией отливки крупных серебряных и бронзовых предметов, делали проволоку и тонкую золотую фольгу, применяли пайку, украшали изделия красным камнем или цветным стеклом, вставленным в цилиндрические гнезда. Бесспорно, для мастеров, владеющих такими навыками, изготовить бронзовые кресты с инкрустацией не составляло большого труда. Вместе с крестами в местных мастерских из тех же материалов (бронзовой пластины и желтого прозрачного стекла), в одинаковой технике делали несколько типов украшений серьги с полым многогранником и различные подвески для ожерелий (рис. $3,1,4,5 ; 4,5)$ [13, с. 196-197, рис. 2].

В могильнике у с. Лучистое кресты найдены в трех детских погребениях (рис. 3) и в двух захоронениях женщин (рис. 4). Возраст погребенных с крестами девочек - 1,5-2 года (склеп 268), $4( \pm 1)$ года (склеп 79) и 8-10 лет (склеп 100). Из-за плохой сохранности костяков, точный возраст женщин определить не удалось. Судя по большим пряжкам и парным фибулам, сопровождавшим захоронения, можно говорить о том, что речь идет о замужних женщинах, для костюма которых были характерны перечисленные аксессуары. Эти женщины носили ожерелья с крестами в парадном костюме - поверх платья, опоясанного широким ремнем с большой пряжкой с прямоугольным щитком с вытисненным изображением льва (рис. 4,1,8). Наряд дополнялся накидкой, пристегнутой к платью двупластинчатыми фибулами (рис. 4,3 ) или византийскими прогнутыми подвязными застежками (рис. 4,6,7).

Во всех погребениях кресты лежали среди бус, на шейных позвонках и в верхней части грудной клетки. Ожерелья из склепов 100 и 122а составлены из янтарных эллипсоидных, уплощенных небольших бусин длиной $0,8-$ 1,8 см, чередующихся с бисером из черного глухого стекла (рис. 2,1,3). В них также присутствуют несколько крупных 14-гранных бусин из темно-синего стекла. В ожерельях из детских погребений из склепов 79 и 268 преобладают бусы из черного, синего или зеленого стекла (рис. 2,2,4). Янтарные бусины представлены в них несколькими экземплярами. Описанные ожерелья - небольшие, их длина 16-34 см. 


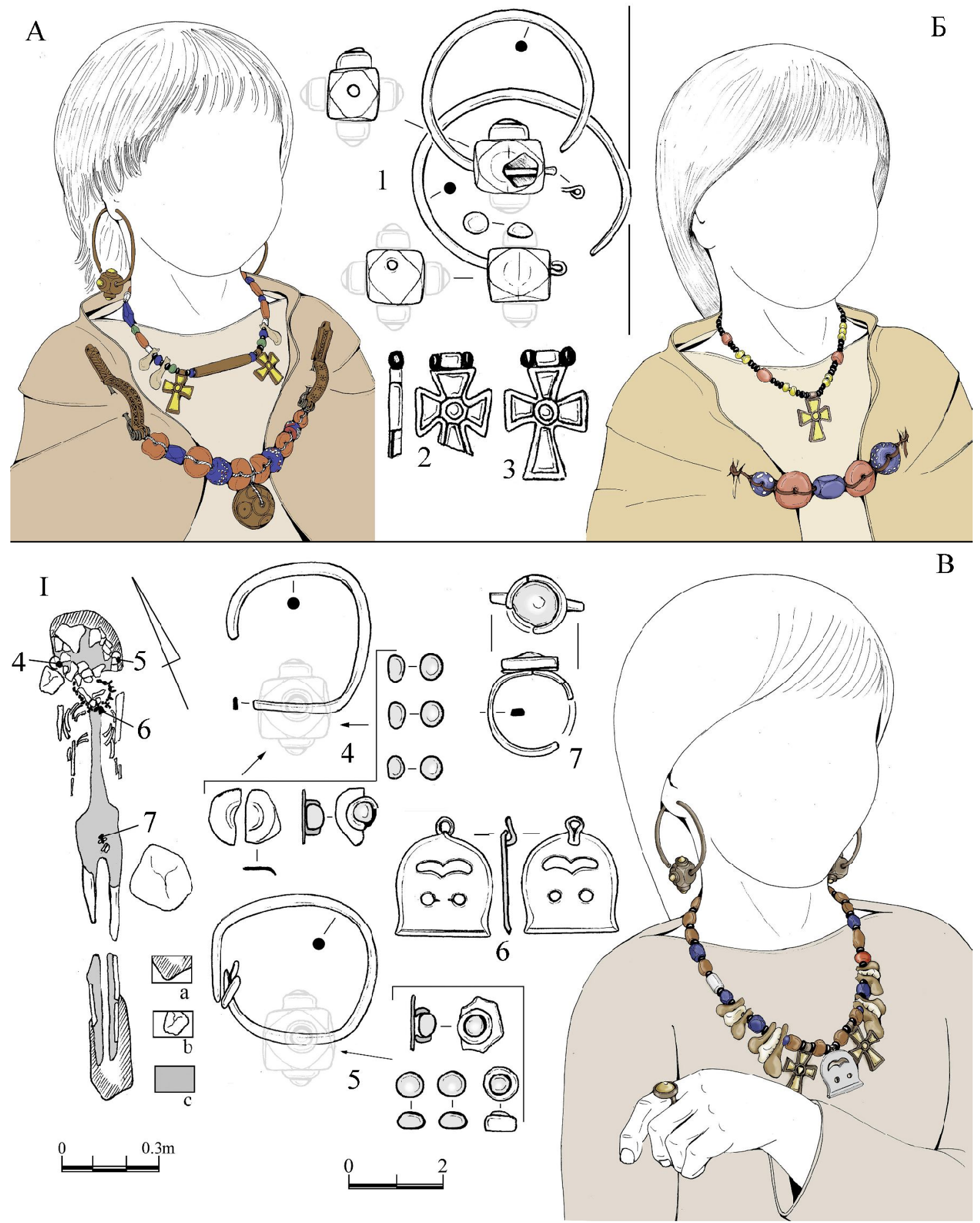

Рис. 3. Могильник у с. Лучистое. Детские погребения с крестами второй половины VI - начала VII в.

Fig. 3. Cemetery near the village of Luchistoye. Children's burials with crosses of the second half of the $6^{\text {th }}$ - early $7^{\text {th }}$ centuries 


\section{ВИЗАНТИЙСКАЯ ТАВРИКА}

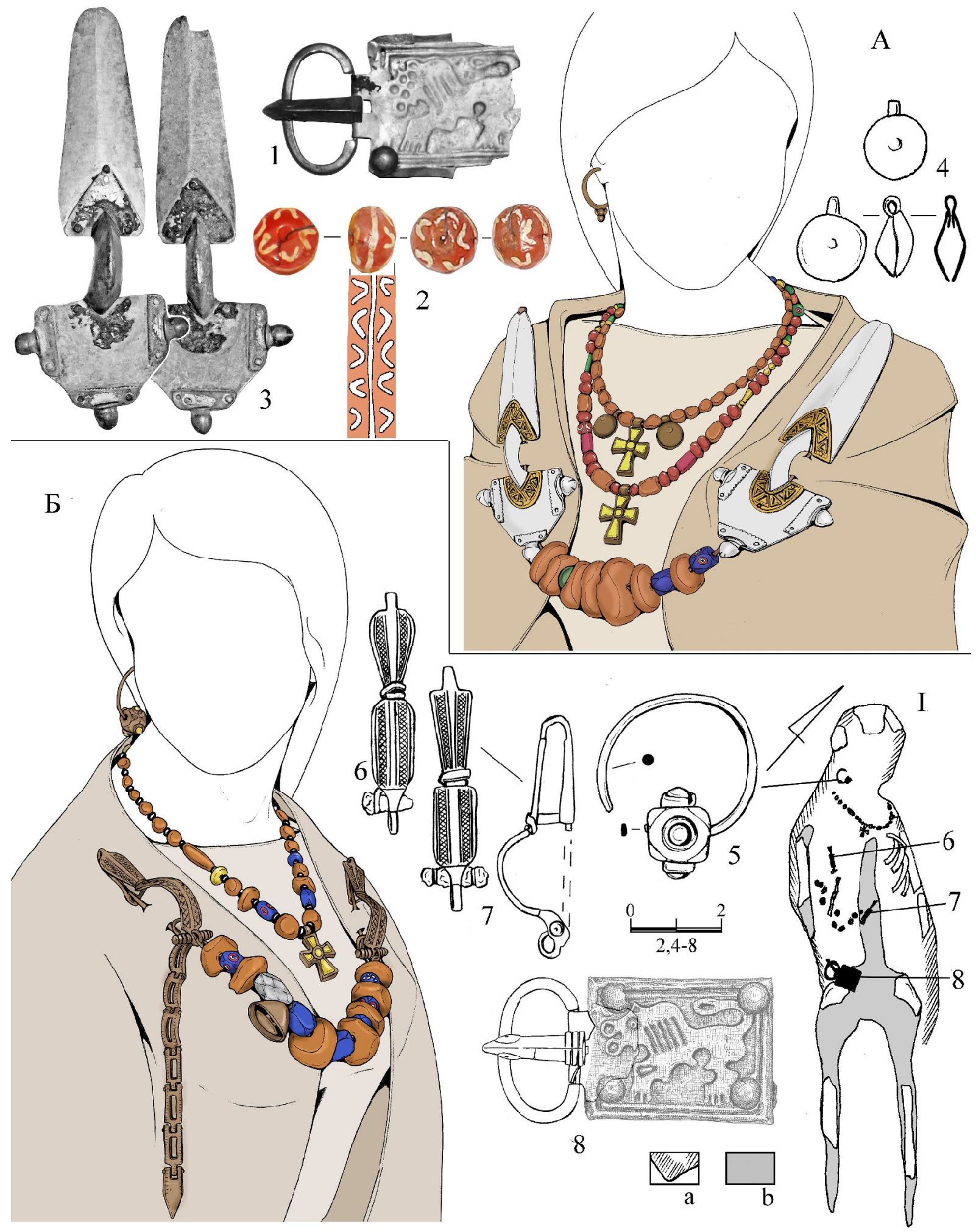

Рис. 4. Могильник у с. Лучистое. Женские погребения с крестами первой четверти VII в.

Fig. 4. Cemetery near the village of Luchistoye. Female burials with crosses of the first quarter of the $7^{\text {th }}$ century 
В погребении из склепа 102 бусы лежали в два ряда (рис. 4, А). В верхнем ряду располагалось 30 небольших сферических и эллипсоидных уплощенных янтарных бусин и около десятка стеклянных, в основном, сферических из желтого и зеленого стекла; в нижнем - несколько янтарных и стеклянных, а также 27 сердоликовых сферических бусин. Одна из сердоликовых бусин инкрустирована белой краской (рис. 4,2). В позднеантичное и раннесредневековое время украшенные подобным образом сердоликовые бусы производились в Иране, Индии и имели широкое распространение на территории от Восточного Средиземноморья до Юго-Восточной Азии [7, с. 141-142; 24, S. 221-278]. В ЮгоЗападном Крыму инкрустированные сердоликовые бусины найдены в погребениях VIIVIII вв. из Эски-Кермена, Алмалык-Дере (Мангуп), Скалистого и Лучистого. В Крым, скорее всего, они поступали с Северного Кавказа, куда в большом количестве привозились из Ирана [7, с. 142].

В центре ожерелий из склепов 79 и 122а размещалось по одному кресту (рис. 2,2,3). В состав ожерелий из склепов 100, 102 и 268 входило по два креста. В коротких низках бус из детских погребений кресты находились с двух сторон от центрального украшения - подвески из геральдической поясной бляшки (рис. 2,1) или цилиндрической пронизи, скрученной из бронзовой пластины (рис. 2,4). От расположенных рядом янтарных бусин кресты отделялись черным бисером. В момент обнаружения крестов бисерины плотно прилегали к петелькам с двух сторон (рис. 3,2,3). В двухрядном ожерелье из склепа 102 кресты висели по центру каждого ряда (рис. 4, А).

Вместе с инкрустированными крестами в ожерельях носили подвески, выполненные из различных материалов. В детских ожерельях из склепов 100 и 268 использованы просверленные зубы оленя (рис. 2,1b,4b). В ожерелье из склепа 100 семь подвесок из зубов оленя подвесили парами с двух сторон от крестов, разместив внутри каждой пары по небольшой раковине моллюска Cypraea moneta с обрезанной лицевой частью (рис. 2,1c).

Подвески из зубов оленя часто встречаются в ожерельях VI-VII вв. женщин и девочек из Юго-Западного Крыма. Как прави- ло, в ожерелья включали по 1-3 подвески, реже число их достигало семи (рис. 2,1) или даже семнадцати. Подвески из зубов оленя, безусловно, служили амулетами. С эпохи античности существовало представление об олене, как борце со змеями. Плиний Старший приводит множество рецептов лекарств из рога, костей и шкуры оленя против укуса змеи, а также сообщает о том, что имея при себе даже один зуб оленя, можно обратить в бегство змею [29, р. 275, XXVIII, 42.2]. В средние века олень, уничтожающий змей, уподоблялся Христу, побеждающему зло [41, p. 10-11]. Возможно поэтому в ожерельях христиан часто рядом с крестом помещали зуб оленя. В собрании Российского этнографического музея хранится происходящая с Северного Кавказа цепь конца XVII-XVIII вв., на которой рядом с крестом укреплена подвеска из зуба оленя в серебряной оправе [11, кат. № 170]. Находки подобного рода показывают, что традиция ношения в одном наборе этих двух предметов существовала долго, вплоть до Нового времени.

Подвески из небольших раковин каури также относятся к амулетам. По этнографическим данным, у среднеазиатских народов раковины каури предохраняли носящего от болезней и дурного глаза [6, с. 22]. На Кавказе, у многих народов раковины каури связывались с лечебной и предохранительной магией: их прикрепляли к больному месту, носили на шее, подвешивали к колыбели ребенка $[8$, с. $60-61$, рис. 33]. В Северном Причерноморье раковины каури, привозившиеся из теплых, тропических морей, использовались в ожерельях с эпохи античности. В Юго-Западном Крыму, во второй половине VI - первой половине VII вв. женщины и девочки часто включали в свои ожерелья по 1-4 подвески из раковин каури. В склепе 38 из могильника у с. Лучистое, в одном из женских погребений второй половины VII в., найдено ожерелье, в состав которого входило 19 подвесок из раковин каури [3, таб. 132,2a; 185,1].

Центральная подвеска ожерелья из склепа 100 сделана из серебряной поясной геральдической бляшки с прорезным орнаментом в виде «личины» (рис. 2,1a). Такие бляшки характерны для мужских воинских поясов второй половины VI-VII вв.: с их помощью к ос- 
новному ремню прикрепляли небольшие вспомогательные ремешки. В Юго-Западном Крыму в эпоху раннего средневековья детали мужской поясной гарнитуры часто переделывали в подвески, которые носили в ожерельях с бусами женщины и дети. Для этих целей использовали геральдические поясные бляшки и наконечники вспомогательных ремней, в верхней части которых просверливалось отверстие и вставлялась проволочная петелька [3, таб. 107,6] или, как в случае с подвеской из склепа 100, скоба для крепления на ремне переделывалась в петельку для подвешивания (рис. 3,6). Особой популярностью пользовались геральдические бляшки с изображением «личины». Отметим, что во второй половине VI - первой половине VII в. женщины крымских готов носили еще и пряжки с геральдическими щитками с аналогичным декором. Использование в женском костюме пряжек и подвесок из бляшек с «личиной», видимо, связано с определенным восприятием древними этого изображения. Возможно, стилизованное человеческое лицо призвано было отпугивать «злые силы», а предметы одежды, украшенные таким сюжетом, воспринимались в качестве оберега, защищающего его носителя.

В ожерелье из склепа 102 с двух сторон от креста размещались две бронзовые подвески линзовидной формы диаметром $1,1 \mathrm{~cm}$ (рис. 4,4$)$. Такие подвески, сделанные из бронзы или золота, бытовали в Юго-Западном Крыму во второй половине VI - первой половине VII в. [13, с. 196-197, рис. $6,7 a ; 8,8 ; 10]$. Аналогичные украшения, считающиеся поздней разновидностью римских булл, были популярными в Византии и у варварских народов на сопредельных территориях в VI первой половине VII в., о чем свидетельствуют находки из Северной Италии, Болгарии и Малой Азии [34, fig. 5, 41; 43, pl. 50,884,885; 19, Cat. Nr. III.28.n-o; 18, p. 72]. Золотые линзовидные подвески часто присутствуют в одном наборе с крестом.

Ношение креста в ожерелье или в качестве подвесок к украшениям - брошам или серьгам, было распространено в христианском мире в эпоху раннего средневековья. Судя по находкам из кладов, византийские «аристократки» подвешивали богато украшенные золотые кресты на цепи вместе с различными подвесками и медальонами [32, Pl. 5, H$G]$. В качестве примера использования креста в составе нагрудного украшения можно привести и тунику Батильды, супруги франкского короля Хлодвига II, умершей в 680 г. в основанном ею аббатстве Шелль. На передней стороне туники цветной шелковой нитью вышита имитация носившихся королевой в светской жизни богатых украшений, состоящих из нескольких колье, к которым подвешены медальоны и большой крест с инкрустацией [38, p. 100-101]. Ожерелья из стеклянных бусин, включавшие подвесные кресты известны по находкам VI-VII вв. из византийских памятников Подунавья и Сирии [30, P1. 22, 134; 25 , Kat. Nr. 10], а также из погребений гепидов [22, Taf. 124,10-14] и франков [20, Fig. II; 42, p. 358-359].

В трех из пяти описанных ожерелий из могильника у с. Лучистое присутствуют парные кресты. В могильниках Юго-Западного Крыма найдены и другие ожерелья раннесредневекового времени, в состав которых входило по 2-4 креста. Парные кресты выявлены в двух погребениях конца VI - первой четверти VII в. и в захоронении VIII в. из некрополей Эски-Кермена и Лучистого [31, Fig. 7,2; $9,1 ; 14$, рис. 1,1$]$. В Скалистом, в склепе 478, в погребении второй половины VIII-IX вв. вместе с 92-мя бусинами лежали три проволочных креста, отличающихся размерами [5, рис. $87,23,25,26$. Четыре одинаковых креста зачищено в женском погребении второй половины VI в. из Лучистого, из склепа 207 [31, Fig. 7,3].

В Крыму обычай использования нескольких крестов прослеживается и в более позднее время. В городском некрополе Судак II, в могиле 133 конца XII - первой половины XIII в. на костяке зачищены бронзовые энколпион и крест с циркульным орнаментом [10, рис. $83,8,9]$. На городище Эски-Кермен, в квартале 1, в подвале одной из усадеб, погибшей в пожаре в конце XIII в., найдено ожерелье, в состав которого наряду с бусами и бубенчиками входил набор из бронзовых креста с рельефным изображением распятия, створки энколпиона с рельефным изображением распятия и подвески в виде креста, включенного в круг. Интересно, что потомки крым- 
ских христиан, переселенных в 1778 г. из ЮгоЗападного Крыма в Приазовье, носили в ожерельях по несколько крестов вплоть до начала $\mathrm{XX}$ в. При этом количество крестов в некоторых ожерельях достигало семи - восьми экземпляров [9, с. 23, 49].

Ношение нескольких крестов, безусловно, связано с восприятием креста в качестве защитного средства. Видимо в представлении древних христиан оберегающая сила возрастала с увеличением количества крестов, носившихся при себе. Традиция ношения нескольких крестов в ожерельях известна как в Византии, так и у варварского христианского населения Европы. В состав византийских кладов из Истрии VI в. и Кесарии Морской рубежа VI-VII вв. входило по два креста и по набору украшений, предназначавшемуся для одного человека [26, fig. 292-293; 32, Pl. 1,G; $4, H-K ; 5, E]$. В погребениях франкских женщин VI в. из Кельна, из церкви Св. Северина и из некрополя Гре-Дуасо (Бельгия) найдены ожерелья, в состав которых входило по три креста [20, Fig. II; 42, p. 358-359]. В музее г. Кютахья (Турция) хранится раннесредневековая подвеска из четырех крестов, укрепленных на дужке серьги с литым многогранником, которая служит подтверждением возможности одновременного ношения нескольких крестов в одном наборе [14, рис. 1, 3$]$.

В эпоху раннего средневековья существовала практика подвешивать несколько крестов к различным украшениям или аксессуарам одежды. Тремя одинаковыми золотыми крестами на отдельных цепочках декорирована дужка византийской серьги VI в., хранящейся в коллекции Галереи Уолтерса [45, Kat. Nr. 53]. Два пластинчатых серебряных креста укреплено в проволочных петельках, подвешенных к щитку серьги VII в. из могильника Альтенердинг [36, Taf. 61,459/2; 203,10]. Круглая брошь из клада $V$ в., найденного в Алжире, была украшена тремя золотыми крестами, припаянными к петелькам на месте несохранившихся первоначальных подвесок [28, Pl. I; XXXII, 1]. Центральный крест в этой композиции имел более крупные размеры и был покрыт гравированным растительным декором. Считается, что три креста, расположенные таким образом, символизировали сцену Распятия [28, p. 70-71]. Аналогично размещены и три золотых креста, подвешенные к оправе ранневизантийской геммы из горного хрусталя с выгравированной хризмой, найденной в Сирии, в районе Алеппо [37, Pl. 136, X142].

В V-VII вв. в Византии были популярны ожерелья с многочисленными крестовидными подвесками из золотой проволоки и бус [44, fig. 146-147; 23, Kat. Nr. 487, 492]. В таких ожерельях присутствовало от трех до тринадцати или пятнадцати крестовидных подвесок. В Анемуриуме (Киликия) в могиле рубежа VI-VII вв. найден набор из 10 нашивных бляшек в форме ажурного креста и 7 бляшек с прорезанным в центре крестом предназначавшихся, видимо, для украшения горловины платья [35, fig. 12]. На коптских туниках V-XI вв. часто встречаются вытканные изображения нескольких крестов, помещенных на клавах декоративных вставках-полосах или в медальонах [27, Kat. Nr. 86, 87, 93-95].

Подводя итоги, можно отметить следующее. Происходящие из могильника у с. Лучистое, из погребений второй половины VI первой четверти VII в. кресты с инкрустацией относятся к самому раннему типу бытовавших в Юго-Западном Крыму подвесных индивидуальных крестов. Скорее всего, их делали местные мастера по привозным византийским образцам. В Юго-Западный Крым импортная византийская продукция поступала в основном через Херсон, который уже со второй половины V в. был главным экономическим партнером для жителей страны Дори, снабжавших его недостающей сельскохозяйственной продукцией.

Кресты носили девочки и замужние женщины, на шее, но не на отдельном шнурке, а в обычных ожерельях, вместе с бусами и различными амулетами - зубами оленя, раковинами каури, подвеской с оберегающим от злых сил изображением «личины» или линзовидными подвесками. Публикуемые находки являются важным источником для изучения раннего этапа истории христианства в Юго-Западном Крыму. Они не только характеризуют материальную культуру, но и дают представление о духовной жизни местного населения. Находки подобного рода являются ярким свидетельством тесных экономических и культурных связях региона с Византийской империей в эпоху раннего средневековья. 


\section{ПРИМЕЧАНИЕ}

1 Работа подготовлена в рамках фундаментальной темы «Кросс-культурные связи населения Таврики и близлежащих территорий в эпоху средневековья» (0832-2015-0007), утвержденной государственным заданием отделу средневековой археологии ФГБУН «Институт археологии Крыма РAH».

\section{СПИСОК ЛИТЕРАТУРЫ}

1. Айбабин, А. И. Некоторые аспекты истории Готской епархии в Юго-Западном Крыму / А. И. Айбабин // Материалы по археологии, истории и этнографии Таврии. - 2006. - Вып. XII. C. 615-626.

2. Айбабин, А. И. О локализации области Дори / А. И. Айбабин // Материалы по археологии, истории и этнографии Таврии. - 2015. - Вып. ХХ. C. 311-332.

3. Айбабин, А. И. Могильник у села Лучистое. Т. І. Раскопки 1977, 1982-1984 гг. / А. И. Айбабин, Э. А. Хайрединова. - Симферополь ; Керчь : АДЕФ-Украина, 2008. - 336 с.

4. Айбабин, А. И. Могильник у села Лучистое. Т. II. Раскопки 1984, 1986, 1991, 1993-1995 гг. / А. И. Айбабин, Э. А. Хайрединова. - Симферополь ; Керчь : Майстер Книг, 2014. - 400 с.

5. Веймарн, Е. В. Скалистинский могильник / Е. В. Веймарн, А. И. Айбабин. - Киев : Наукова думка, 1993. - $201 \mathrm{c.}$

6. Гущина, И. И. «Золотое кладбище» римской эпохи в Прикубанье / И. И. Гущина, И. П. Засецкая. - СПб. : Фарн, 1994. - 172 с.

7. Деопик, В. Б. Классификация и хронология аланских украшений / В. Б. Деопик // Материалы и исследования по археологии СССР. - 1963. - № 114. Средневековые памятники Северной Осетии. С. $122-147$.

8. Иерусалимская, А. А. Мощевая Балка / А. А. Иерусалимская. - СПб. : Изд-во Гос. Эрмитажа, 2012. - 384 c.

9. Крым в Приазовье. Культура и этнография мариупольских греков : Каталог выставки. - Симферополь ; Мариуполь : [б. и.], 2011. - 52 с.

10. Майко, В. В. Средневековые некрополи Судакской долины / В. В. Майко. - Киев : Академпериодика, 2007. $-270 \mathrm{c}$.

11. Островский, А. Б. Русский православный крест в собрании Российского этнографического музея / А. Б. Островский. - СПб. : Арт-Палас, 2007. $348 \mathrm{c}$.

12. Хайрединова, Э. А. Раннесредневековые кресты из Юго-Западного Крыма / Э. А. Хайреди- нова // Материалы по археологии, истории и этнографии Таврии. - 2007. - Вып. ХIII. - С. 151-182.

13. Хайрединова, Э. А. Бронзовые серьги с полым многогранником из могильника у с. Лучистое / Э. А. Хайрединова // Материалы по археологии, истории и этнографии Таврии. - 2013. - Вып. XVIII. С. 187-216.

14. Хайрединова, Э. А. Ожерелья с крестами последней четверти VI - VII в. из некрополя ЭскиКермена / Э. А. Хайрединова // Владимирский сборник : материалы Международных научных конференций «I и II Свято-Владимирские чтения». - Калининград : Рос-Доафк, 2016. - С. 280-299.

15. Якобсон, А. Л. Раннесредневековый Херсонес / А. Л. Якобсон // Материалы и исследования по археологии СССР. № 63. - М.; Л. : Изд-во АН CCCP, 1959. - $364 \mathrm{c}$.

16. Ajbabin, A. I. Archäologie und Geschichte der Krim in byzantinischer Zeit / A. I. Ajbabin. - Mainz : Verl. des Römisch-Germanisches Zentralmuseum, 2011. - 276 S.

17. Atanasov, G. Martirium 'АГІА $\Sigma$ MON dans le castel basbyzantin près du village de Golech, région de Silistra / G. Atanasov // Miscellanea Bulgarica. 1997. - Vol. 11. - P. 127-139.

18. Balabanov, T. Gothic Bishop's centre from the $4^{\text {th }}-6^{\text {th }}$ century near the village of Khan Kroum, Soumen region / T. Balabanov // Goterna. - 2006. - Vol. II. P. 71-77.

19. Bierbrauer, V. Archeologia degli Ostrogoti in Italia / V. Bierbrauer // I Goti. - Milano : Electa, 1994. P. 170-213.

20. Brown, K. The gold breast chain from the early byzantine period in the Römisch-Germanisches Zentralmuseum / K. Brown. - Mainz : Verl. des Römisch-Germanisches Zentralmuseum, 1984. - 30 p.

21. Campanati, R. F. La cultura artistica nelle regioni bizantini d'Italia dal VI all'XI secolo / R. F. Campanati // I Bizantini in Italia. - Milano : Lib. Scheiwiller, 1982. - P. 137-426.

22. Csallàny, D. Archäologische Denkmäler der Gepiden im Mitteldonaubecken (454-568 u.Z.) / D. Csallàny. - Budapest : Verl. d. Ung. Acad. d. Wiss., 1961. $-406 \mathrm{p}$.

23. Die Welt von Byzanz. Europas Östliches Erbe / Hrsg. L. Wamser. - München : Theiss, 2004. - 475 S.

24. Eger, Ch. Indisch, Persisch oder Kaukasisch? Zu den Karneolperlen mit Ätzdekor der Grouppe C nach Beck und den östlichen Fernkontakten der Provinz Arabia / Ch. Eger // Jahrbuch des RömischGermanisches Zentralmuseum. - 2010. - Bd. 57. S. 221-278.

25. Die Kunst der frühen Christen in Syrien. Zeichen, Bilder und Symbole vom 4. bis 7. Jahrhundert / Hrsg. M. Fansa, B. Bollmann. - Mainz : Verl. Philipp von Zabern, 2008. - 220 S. 
26. Frova, A. Il tesoretto aureo e il reliquiario / A. Frova // Scavi di Caesarea Maritima. - Milano : Accad. di scienze e lettere, 1965. - P. 235-246.

27. Christliches mit Feder und Faden / Hrsg. J. Henner, H. Förster, U. Horak // Nilus. Studien zur Kultur Ägyptens und des Vorderen Orients. Bd. 3. Wien : ÖVG, 1999. - $128 \mathrm{~S}$.

28. Heurgon, J. Le trésor de Ténès / J. Heurgon. Paris: Arts et métiers graphiques, 1958. -75 p.

29. Histoire naturelle de Pline. T. II / trad. en fr. par É. Littré. - Paris : L'inst. de France, 1877. - 708 p.

30. Ivanišević, V. Les nécropoles de Viminacium à l'époque des Grandes migrations / V. Ivaniševiæ, M. Kazanski, A. Mastykova. - Paris : ACHCByz, 2006. $-351 \mathrm{p}$.

31. Khairedinova, E. A. Early Medieval Crosses from the South-Western Crimea / E. A. Khairedinova // Byzas. - 2012. - Vol. 15. - P. 417-440.

32. Manière-Lévêque, A.-M. L'évolution des bijoux «aristocratiques» féminins à travers les trésors proto-byzantins d'orfèvrerie / A.-M. Manière-Lévêque // Revue Archéologique. - 1997. - № 1. - P. 79-106.

33. Procopius. Opera Omnia. Vol. IV. De Aedificiis / eds. J. Haury, G. Wirth. - Lipsiae : Teubner, 1964. $406 \mathrm{~S}$.

34. Russell, J. Byzantine Instrumenta Domestica from Anemurium: the significance of context / J. Russell // City, Town and countryside in the Early Byzantine Era / ed. R. L. Hohlfelder. - New York : Columbia Univ. Press, 1982. - P. 133-164.

35. Russell, J. Christianity at Anemurium (Cilicia). Recent discoveries / J. Russell // Actes du XIe congrès international de l'archéologie chrétienne. - Rome : École Fr. de Rome, 1989. - Vol. II. - P. 1621-1637.

36. Sage, W. Das Reihengräberfeld von Altenerding in Oberbayern / W. Sage // Germanische Denkmäler der Völkerwanderungszeit. Serie A, Band XIV. - Berlin : Gebrüder Mann, 1984. - 356 S.

37. Spier, J. Late Antique and Early Christian Gems / J. Spier. - Wiesbaden : Reichert Verl., 2007. - 221 p.

38. Vaklinova, M. Mittelalterliche Schmuckstücke aus Bulgarien / M. Vaklinova. - Sofia : Septemvri, 1981. $-80 \mathrm{p}$.

39. Vallet, F. De Clovis à Dagobert. Les Mérovingiens / F. Vallet // Découvertes Gallimard. No. 268. - Paris : Gallimard, 1997.-176p.

40. Vinski, Z. Krstoliki nakit epohe seobe naroda u Jugoslaviji / Z. Vinski // Vjesnik Arheološkog muzeja u Zagrebu. - 1968. - Vol. III. - P. 103-166.

41. Voisenet, J. L'animal et la pensée médicale dans les textes du Haut Moyen Age / J. Voisenet. Electronic text data. - Mode of access: http://rursus. revues.org/50 (date of access: 12.06.2017). - Title from screen.

42. Vrielynck, O. The «Lady» of Grez-Doiceau (Belgium) / O. Vrielynck // Rome and the Barbarians.
The Birth of a new World / ed. J.-J. Aillagon. - Milano : Scira Publ., 2008. - P. 358-359.

43. Waldbaum, J. C. Metalwork from Sardis / J. C. Waldbaum. - Cambridge, MA : Harvard UP, 1983. $-216 \mathrm{p}$.

44. Walker, A. Enhancing the Body, Neglecting the Soul? / A. Walker // Byzantine Women and Their World / ed. I. Kalavrezou. - Harvard : Art Museums, 2003. - P. 233-274.

45. Yeroulanou, A. Diatria. Gold pierced-work jewellery from the $3^{\text {rd }}$ to the $7^{\text {th }}$ century/A. Yeroulanou. Athens : Benaki Museum, 1999. - 320 p.

\section{REFERENCES}

1. Aybabin A.I. Nekotorye aspekty istorii Gotskoy eparkhii v Yugo-Zapadnom Krymu [Some Aspects of the History of Gothian Diocese in the South-Western Crimea]. Materialy po arkheologii, istorii $i$ etnografii Tavrii [Materials in Archeology, History and Ethnography of Tauria], 2006, vol. XII, pp. 615-626.

2. Aybabin A.I. O lokalizatsii oblasti Dori [On the Location of the Region of Dori]. Materialy po arkheologii, istorii $i$ etnografii Tavrii [Materials in Archeology, History and Ethnography of Tauria], 2015, vol. XX, pp. 311-332.

3. Aybabin A.I., Khayredinova E.A. Mogilnik u sela Luchistoe. T. I. Raskopki 1977, 1982-1984 gg. [Burial Mound near the Village of Luchistoe. Vol. I. Excavations of 1977, 1982-1984]. Simferopol; Kerch, ADEF-Ukraina Publ., 2008. 336 p.

4. Aybabin A.I., Khayredinova E.A. Mogilnik $u$ sela Luchistoe. T. II. Raskopki 1984, 1986, 1991, 1993-1995 gg. [Burial Mound near the Village of Luchistoe. Vol. II. Excavations of 1984, 1986, 1991, 19931995]. Simferopol; Kerch, Maister Knig Publ., 2014. $400 \mathrm{p}$.

5. Veymarn E.V., Aybabin A. I. Skalistinskiy mogilnik [Cemetery of Skalistoe]. Kiev, Naukova dumka Publ., 1993. 201 p.

6. Gushchina I.I., Zasetskaya I.P. "Zolotoe kladbishche» rimskoy epokhi v Prikubanye ["Golden Cemetery" of the Roman Age in the Kuban Region]. Saint Petersburg, Farn Publ., 1994. 172 p.

7. Deopik V.B. Klassifikatsiya i khronologiya alanskikh ukrasheniy [Classification and Chronology of Alan Jewelry]. Materialy $i$ issledovaniya po arkheologii SSSR [Materials and Research on Archaeology of the USSR], 1963, vol. 114, pp. 122-147.

8. Ierusalimskaya A.A. Moshchevaya Balka. Saint Petersburg, Izd-vo Gos. Ermitazha, 2012. 384 p.

9. Krym v Priazovye. Kultura i etnografiya mariupolskikh grekov. Katalog vystavki [Crimea in the Azov Sea Region. Culture and Ethnography of the 
Mariupol Greeks. Exhibition Catalogue]. Simferopol; Mariupol, 2011. 52 p.

10. Mayko V.V. Srednevekovye nekropoli Sudakskoy doliny [Medieval Necropolises of the Sudak Valley]. Kiev, Akademperiodika Publ., 2007. 270 p.

11. Ostrovskiy A.B. Russkii pravoslavnyi krest v sobranii Rossiiskogo etnograficheskogo muzeia [Russian Orthodox Cross in the collection of the Russian Ethnographic Museum]. S.-Petersburg, ArtPalas Publ., 2007. 348 p.

12. Khayredinova E.A. Rannesrednevekovye kresty iz Yugo-Zapadnogo Kryma [Early Medieval Crosses from the South-Western Crimea]. Materialy po arkheologii, istorii i etnografii Tavrii [Materials in Archeology, History and Ethnography of Tauria], 2007, vol. XIII, pp. 151-182.

13. Khayredinova E.A. Bronzovye sergi s polym mnogogrannikom iz mogilnika u s. Luchistoe [Bronze Earrings with a Hollow Polyhedron from the Burial Mound of Luchistoe Village]. Materialy po arkheologii, istorii $i$ etnografii Tavrii [Materials in Archeology, History and Ethnography of Tauria], Simferopol, 2013, vol. XVIII, pp. 187-216.

14. Khayredinova E.A. Ozherelya s krestami posledney chetverti VI-VII vekov iz nekropolya EskiKermena [Necklaces with Crosses of the Last Quarter of the $6^{\text {th }}-7^{\text {th }}$ Centuries from the Necropolis of Eski Kermen]. Vladimirskiy sbornik. Materialy mezhdunarodnykh nauchnykh konferentsiy "I i II Svyato-Vladimirskie chteniya» [' ${ }^{\text {st }}$ and $2^{\text {nd }}$ St. Vladimir's Readings'. Materials of the First and Second International Scholary Conferences], Kaliningrad, Ros-Doafk Publ., 2016, pp. 280-299.

15. Yakobson A.L. Rannesrednevekovyy Hersones [Early Medieval Chersonesus]. Materialy $i$ issledovaniya po arkheologii SSSR [Materials and Research on Archaeology of the USSR]. Moscow; Leningrad, Izd-vo AN SSSR, 1959, vol. 63. 364 p.

16. Ajbabin A.I. Archäologie und Geschichte der Krim in byzantinischer Zeit. Mainz, Verl. des RömischGermanisches Zentralmuseum, 2011. 276 p.

17. Atanasov G. Martirium 'АГІА $\Sigma$ MON dans le castel basbyzantin près du village de Golech, région de Silistra. Miscellanea Bulgarica, 1997, vol. 11, pp. 127-139.

18. Balabanov T. Gothic Bishop's centre from the $4^{\text {th }}-6^{\text {th }}$ century near the village of Khan Kroum, Soumen region. Goterna, 2006, vol. II, pp. 71-77.

19. Bierbrauer V. Archeologia degli Ostrogoti in Italia. I Goti. Milano, Electa Publ., 1994, pp. 170-213.

20. Brown $\mathrm{K}$. The gold breast chain from the early byzantine period in the Römisch-Germanisches Zentralmuseum. Mainz, Verl. des RömischGermanisches Zentralmuseum, 1984. 30 p.

21. Campanati R. F. La cultura artistica nelle regioni bizantini d'Italia dal VI all'XI secolo. I Bizantini in Italia, Milano, Lib. Scheiwiller Publ., 1982, pp. 137-426.

22. Csallàny D. Archäologische Denkmäler der Gepiden im Mitteldonaubecken (454-568 u.Z.). Budapest, Verl. d. Ung. Acad. d. Wiss., 1961. 406 p.

23. Wamser L., ed. Die Welt von Byzanz. Europas Östliches Erbe. München, Theiss Publ., 2004. 475 p.

24. Eger Ch. Indisch, Persisch oder Kaukasisch? $\mathrm{Zu}$ den Karneolperlen mit Ätzdekor der Grouppe C nach Beck und den östlichen Fernkontakten der Provinz Arabia. Jahrbuch des Römisch-Germanisches Zentralmuseum, 2010, vol. 57, pp. 221-278.

25. Fansa M., Bollmann B., eds. Die Kunst der frühen Christen in Syrien. Zeichen, Bilder und Symbole vom 4. bis 7. Jahrhundert. Mainz, Verl. Philipp von Zabern, 2008. 220 p.

26. Frova A. Il tesoretto aureo e il reliquiario. Scavi di Caesarea Maritima, Milano, Accad. di scienze e lettere Publ., 1965, pp. 235-246.

27. Henner J., Förster H., Horak U., eds. Christliches mit Feder und Faden. Nilus. Studien zur Kultur Ägyptens und des Vorderen Orients. Vol. 3. Wien, ÖVG, 1999. $128 \mathrm{p}$.

28. Heurgon J. Le trésor de Ténès. Paris, Arts et métiers graphiques Publ., 1958. 75 p.

29. Littré É., ed. Histoire naturelle de Pline. T. II. Paris, L'institut de France Publ., 1877. 708 p.

30. Ivanišević V., Kazanski M., Mastykova A. Les nécropoles de Viminacium à l'époque des Grandes migrations. Paris, ACHCByz Publ., 2006. 351 p.

31. Khairedinova E.A. Early Medieval Crosses from the South-Western Crimea. Byzas, Istanbul, 2012, vol. 15, pp. 417-440.

32. Manière-Lévêque A.-M. L'évolution des bijoux «aristocratiques» féminins à travers les trésors proto-byzantins d'orfèvrerie. Revue Archéologique, 1997, no. 1, pp. 79-106.

33. Procopius. Opera Omnia. Vol. IV. De Aedificiis. Lipsiae, Teubner Publ., 1964. 406 p.

34. Russell J. Byzantine Instrumenta Domestica from Anemurium: the significance of context. Hohlfelder R.L., ed. City, Town and countryside in the Early Byzantine Era. New York, Columbia Univ. Press, 1982, pp. 133-164.

35. Russell J. Christianity at Anemurium (Cilicia). Recent discoveries. Actes du XIe congrès international de l'archéologie chrétienne. Rome, École Fr. de Rome, 1989, vol. II, pp. 1621-1637.

36. Sage W. Das Reihengräberfeld von Altenerding in Oberbayern. Germanische Denkmäler der Völkerwanderungszeit. Serie A, Band XIV. Berlin, Gebrüder Mann Publ., 1984. 356 p.

37. Spier J. Late Antique and Early Christian Gems. Wiesbaden, Reichert Verl., 2007. 221 p.

38. Vaklinova M. Mittelalterliche Schmuckstücke aus Bulgarien. Sofia, Septemvri Publ., 1981.80 p. 
39. Vallet F. De Clovis à Dagobert. Les Mérovingiens. Découvertes Gallimard. No. 268. Paris, Gallimard, 1997. 176p.

40. Vinski Z. Krstoliki nakit epohe seobe naroda u Jugoslaviji. Vjesnik Arheološkog muzeja u Zagrebu, 1968, vol. III, pp. 103-166.

41. Voisenet J. L'animal et la pensüe müdicale dans les textes du Haut Moyen. URL: http://rursus.revues. org/50 (accessed June 12, 2017).

42. Vrielynck O. The «Lady» of Grez-Doiceau (Belgium). Aillagon J.-J., ed. Rome and the Barbarians.
The Birth of a new World. Milano, Scira Publ., 2008, pp. 358-359.

43. Waldbaum J. C. Metalwork from Sardis. Cambridge, MA, Harvard UP, 1983. 216 p.

44. Walker A. Enhancing the Body, Neglecting the Soul? Kalavrezou I., ed. Byzantine Women and Their World. Harvard, Art Museums Publ., 2003, pp. 233-274.

45. Yeroulanou A. Diatria. Gold pierced-work jewellery from the $3^{\text {rd }}$ to the $7^{\text {th }}$ century. Athens, Benaki Museum Publ., 1999. 320 p.

\section{Information about the Author}

Elzara A. Khayredinova, Candidate of Sciences (History), Senior Researcher, Department of Mediaeval Archaeology, Institute of Archaeology of Crimea, RAS, Prosp. Vernadskogo, 2, 295007 Simferopol, Russian Federation, khairedinovaz@rambler.ru, https://orcid.org/0000-0002-1362-757X

\section{Информация об авторе}

Эльзара Айдеровна Хайрединова, кандидат исторических наук, старший научный сотрудник отдела средневековой археологии, Институт археологии Крыма РАН, просп. академика В.И. Вернадского, 2, 295007 г. Симферополь, Российская Федерация, khairedinovaz@rambler.ru, https://orcid.org/0000-0002-1362-757X 